\title{
Sexual violence towards females in Matara
}

Rathnaweera RHAl

Department of Forensic Medicine, Faculty of Medicine, Karapitiya, Galle

*Corresponding author: Tel: 0094-772969060. E-mail address:ajithrathnaweera@yahoo.com

MLJSL. Vol 1. No 3. december. pp 08-13

\begin{abstract}
Introduction

Information on sexual violence towards females is inadequate. Some statistics are available, but it is uncertain how accurate they are, as many cases go unreported. Therefore an in depth study should be conducted to explore the real situation.
\end{abstract}

\section{Objective}

Routine data pertaining to victims of alleged sexual violence were analyzed to document epidemiological and socio-economic data and to describe the medico-legal aspects of injuries.

\section{Materials and Methods}

All the sexual violence cases referred to the JMO's office, General hospital, Matara form $1^{\text {st }}$ of January 2012 to $1^{\text {st }}$ of December 2012 were retrospectively analyzed.

\section{Results}

During the study period, 260 victims were referred for medico-legal examination. The age of the victims ranged from 4 years to 62 years. 177 (68\%) victims were between 11 to 16 years of age. Majority (90\%) of the victims belonged to lower socio-economic classes. $210(80 \%)$ had not studied beyond grade 10. The alleged incident had taken place at the victims' house in 110 (42\%) cases. In 148 (57\%) cases, the victim had given "consent" for the alleged act. 22 (8\%) were pregnant at the time of examination. Out of the population $100(38 \%)$ had hymenal tears but out of that, only 11 had fresh tears. Extra genital injuries were present only in $4(1.5 \%)$ cases. The assailant was the boy friend in $149(57 \%)$ cases. Seventy $(27 \%)$ cases were reported from Matara police area followed by Akuressa 43 (17\%).

\section{Conclusions}

Majority were children below 16 years of age belonging to lower socio-economic group. As they were below 16 years, this amounted to statutory rape. Majority had given "consent" for the alleged act and this could be a reason for lack of extragenital injuries together with delayed presentation. This data highlights the magnitude of juvenile sexual abuse especially by the older boy friends and other known people.

Keywords: Sexual violence, hymenal tears, known assailants, statutory rape 


\section{Introduction}

Sexual violence refers to sexual activity where consent is not obtained or freely given [1]. Coercive strategies used in sexual violence may be physical, verbal, or psychological. Sexual violence is a serious public health problem that threatens the health and well-being of individuals across the world. Victims of sexual violence may experience an increased risk of acute and chronic health problems, including injuries resulting from the sexual assault and subsequent health problems and health risk behaviours. For perpetrators, arrest and conviction may result in social and economic costs related to incarceration or community notification and registration laws. The economic burden of sexual violence victimization including medical and mental health care, loss of work, and impact on quality of life was estimated in 1996 to be approximately \$126 billion annually in the United States [1]. Information on sexual violence towards females is inadequate. Some statistics are available, but it is uncertain how accurate they are, as many cases go unreported. The National Intimate Partner and Sexual Violence Survey found that 1 in 5 women and 1 in 71 men experience sexual violence during their lifetimes [2]. In Swedish population-based surveys, $12 \%$ to $34 \%$ of Swedish women have been exposed to some kind of sexual assault during their lifetime [3]. A study conducted in the early 1990s among 899 pre-university and undergraduate students in Sri Lanka revealed that $18 \%$ of boys and $4.5 \%$ of girls had been sexually abused in childhood [4]. Most of the perpetrators were known parties such as relatives, neighbors, teachers and priests. As indicated by the above study, an in depth study should be conducted to explore the real situation.

\section{Materials and Methods}

All the sexual violence cases referred to the JMO's office, General hospital, Matara from $1^{\text {st }}$ of January 2012 to $1^{\text {st }}$ of December 2012 were retrospectively analyzed. The medico legal records of 301 consecutive sexually assaulted cases were evaluated. Of the 301 cases, 21 cases were excluded due to incomplete documentation. Sexual assault cases against males (20) were also excluded. Routine data pertaining to female victims of alleged sexual violence were analyzed to document epidemiological and socio-economic data and to describe the medico-legal aspects of injuries. The different types of assault were defined as penetration (with penis, hand, or foreign object) vaginal, oral, anal or a combination of the three, alternatively others when no penetration was involved but other kinds of touching or kissing had occurred (involving genitals or body parts). Violence was defined as hitting, kicking, holding, attempts of strangulation, or by other means.

Genital injuries were defined when swelling (oedematous tissues), redness (erythemous skin), ecchymoses (skin or mucous membrane discolorations, known as bruising), tears (breaks in tissue including fissures, cracks, cuts and lacerations), and several (more than one of the above mentioned injuries) were observed. The different genital injury locations are defined as vulva, introitus, labia minora, posterior fourchette, hymen, and vagina.

\section{Results}

During the study period, 277 female victims were referred for medico-legal examination with an alleged history of sexual abuse. Out of that 17 cases were excluded as the victims did not recall or were unwilling to relate assault details. The age of the victims ranged from 4 years to 62 years (Table 01). 177 (68\%) victims were between 11 to 16 years of age.

Majority (90\%) of the victims belonged to lower socio-economic classes whereas $8 \%$ to middle classes and only $2 \%$ to higher classes.

$210(80 \%)$ had not studied beyond grade 10.

The alleged incident had taken place at the victims' house in 110 (42\%) cases (Table 02). In 
148 (57\%) cases, the victim had given the "consent" for the alleged act. 22 (8\%) were pregnant at the time of examination.

Table:1 Age distribution of the victims

\begin{tabular}{|l|l|}
\hline Age (Years) & No \\
\hline $1-5$ & $08(3 \%)$ \\
\hline $6-10$ & $17(6.5 \%)$ \\
\hline $11-16$ & $177(68 \%)$ \\
\hline $17-20$ & $30(11.5 \%)$ \\
\hline $21-25$ & $09(3.4 \%)$ \\
\hline $26-30$ & $04(1.5 \%)$ \\
\hline $31-35$ & $03(1.1 \%)$ \\
\hline $36-40$ & $06(2.3 \%)$ \\
\hline $41-45$ & $02(0.7 \%)$ \\
\hline $46-50$ & $03(1.1 \%)$ \\
\hline $51-55$ & 00 \\
\hline $56-60$ & 00 \\
\hline $61-65$ & $01(0.3 \%)$ \\
\hline
\end{tabular}

Table 02 : Alleged place where incident had taken place

\begin{tabular}{|l|l|}
\hline Place & No \\
\hline Victim's home & $110(42 \%)$ \\
\hline Assailant's home & $35(13 \%)$ \\
\hline Hotel/Guest house & $34(13 \%)$ \\
\hline Friend's home & $26(10 \%)$ \\
\hline Relative's home & $26(10 \%)$ \\
\hline Neighbour's home & $28(3 \%)$ \\
\hline Deserted place & $15(5.7 \%)$ \\
\hline Temple & $02(0.7 \%)$ \\
\hline School & $02(0.7 \%)$ \\
\hline Film hall & $02(0.7 \%)$ \\
\hline
\end{tabular}

The alleged abuse was vaginal intercourse in 225 cases followed by kissing in 153 and intercrural intercourse in 91 (Table 03).

Annular hymen 125 (48\%) was the commonest type of hymen found among the population followed by fimbriated $67(25 \%)$ and cresentic $47(18 \%)$. Five $(1.9 \%)$ had attenuated hymen and $16(6 \%)$ had carunculae multiformes.

Ano-genital injuries were present in 154 victims (Table 04).
Table 03: Allegation

\begin{tabular}{|l|l|}
\hline Type of abuse & No \\
\hline Kissing & 153 \\
\hline Fondling & 36 \\
\hline Intercrural intercourse & 91 \\
\hline Oral intercourse & 45 \\
\hline Vaginal intercourse & 225 \\
\hline Anal intercourse & 11 \\
\hline Combination & 241 \\
\hline
\end{tabular}

Table 04: Medical evidence

\begin{tabular}{|l|l|}
\hline Type of injury & No \\
\hline Hymenal tears & 100 \\
\hline Reddening of hymen & 25 \\
\hline Fourcheette tear & 31 \\
\hline Dilated orifice & 71 \\
\hline Loss of vaginal rugae & 61 \\
\hline Anal injuries & 01 \\
\hline Reddening of Labia & 16 \\
\hline Combination & 131 \\
\hline
\end{tabular}

Out of the population $100(38 \%)$ had hymenal tears and out of that, only 11 had fresh tears (Table 05).

Table 05: Nature of the injury

\begin{tabular}{|l|l|}
\hline Type of tear & No \\
\hline Fresh & 11 \\
\hline Partially healed & 14 \\
\hline Old healed & 75 \\
\hline
\end{tabular}

6 o' clock position was the commonest place for hymenal tear followed by 9 o' clock and 3'o clock.

Hymenal tears were observed in 53 annular hymens, 34 fimbriated hymens and 13 cresentic hymens. For annular hymens, $6^{\prime}$ o clock was the commonest place of tear, for fimbriated hymens, 3' o clock and for cresentic hymens, 6' o clock was the commonest place of tear (Table 06).

Extragenital injuries were present only in 4 $(1.5 \%)$ cases and in all 4 cases the assailant was an unknown person.

Abrasion was the Commonest type of injury found. Face was the commonest place to be injured followed by upper limbs and lower 
limbs.

Table 6: location of tear in different types of hymen

\begin{tabular}{llll}
\hline Location & $\begin{array}{l}\text { Annular } \\
\text { hymen }\end{array}$ & $\begin{array}{l}\text { Fimbriated } \\
\text { hymen }\end{array}$ & $\begin{array}{l}\text { Crescentic } \\
\text { hymen }\end{array}$ \\
\hline $\mathbf{3}$ o' clock & 13 & 31 & 03 \\
$\mathbf{5}$ o' clock & 08 & 11 & 03 \\
6 o' clock & 48 & 18 & 13 \\
7 o' clock & 06 & 03 & 06 \\
9 o' clock & 15 & 29 & 04 \\
11 o' & 05 & 06 & 04 \\
clock & & & \\
\hline
\end{tabular}

The assailant was the boy friend in 149 (57\%) cases and only in $8(\%)$, the assailant was an unknown person (Table 7).

Table 7: Assailant

\begin{tabular}{|l|l|}
\hline Assailant & No \\
\hline Boy friend & $149(57 \%)$ \\
\hline Father & $10(3.8 \%)$ \\
\hline Relative & $12(4.6 \%)$ \\
\hline Priest & $02(0.7 \%)$ \\
\hline School teacher & $02(0.7 \%)$ \\
\hline Known person & $77(30 \%)$ \\
\hline Unknown person & $08(3.0 \%)$ \\
\hline
\end{tabular}

The assailants were aged from 14 years to 57 years (Table 8 ). Majority of the assailants were aged between $21-25$ years $103(40 \%)$.

Table 8: Age of the assailant

\begin{tabular}{|l|l|}
\hline Age of the assailant & No \\
\hline$>15$ & $02(0.7 \%)$ \\
\hline $16-20$ & $89(33 \%)$ \\
\hline $21-25$ & $103(40 \%)$ \\
\hline $26-30$ & $24(9 \%)$ \\
\hline $31-35$ & $06(2.3 \%)$ \\
\hline $36-40$ & $15(5.7 \%)$ \\
\hline $41-45$ & $06(2.3 \%)$ \\
\hline $46-50$ & $10(3.8 \%)$ \\
\hline $51-55$ & $04(1.5 \%)$ \\
\hline $56-60$ & $03(1.1 \%)$ \\
\hline
\end{tabular}

Seventy (27\%) cases were reported from Matara police area followed by Akuressa 43 (17\%).

\section{Discussion}

Several studies have been published during the recent years examining genital and nongenital injuries in female sexual assault victims. Sexual assaults by strangers have been reported as more violent and associated with more injuries than assaults by a person known to the victim [5 - 9]. This is in keeping with findings of this study as all the victims who had extragenital injuries had been abused by an unknown person.

Majority of the victims were children below 16 years of age belonging to lower socio-economic group. As they were below 16 years, this had amounted to statutory rape. Extragenital injuries were present only in 4 (1.5\%) cases. Majority had given "consent" for the alleged act and this could be a reason for lack of extragenital injuries.

Seventy (27\%) cases were reported from Matara police area followed by Akuressa 43 (17\%). The reason for these high percentages should be studied separately. The alleged incident took place at the victim's house in majority of cases. Only in very few cases it took place at a deserted place and the assailant was an unknown person. This data highlights the magnitude of juvenile sexual abuse especially by the older boy friends and other known people.

The victim's relationship to the assailant is consistent with earlier international studies $[10,11]$ and the majority of all assaults were committed by a person known to the victim.

Sexual assaults committed by an unknown person comprise $03 \%$ in this study population, which is somewhat lower when compared with studies from the United Kingdom and the United States [5,12].

The alleged abuse was most frequently vaginal intercourse followed by kissing and intercrural intercourse. Ano-genital injuries were present 
in 154 victims. Out of those who complained of vaginal intercourse, 100 had hymenal tears and only 11 had fresh tears. For annular hymens, 60 clock was the commonest place of tear, for fimbriated hymens, 3 o clock and 9 o clock were the commonest place of tear and for cresentic hymens, 6 o clock was the commonest place of tear. This type of pattern has not been described in the literature and further studies should be carried out to get further information in this regard.

Our results, establishing that only a minority of female sexual assault victims have clinical evidence of fresh genital injuries, are supported by previous studies [6,10, and 12].

The genitoanal area has a remarkable healing capacity resulting in injuries disappearing quickly. One of the most important factors in the forensic examination is therefore the time lapse between the sexual assault and the examination. An examination after 72 hours will not show minor lacerations that might have been present earlier.

This study has some limitations and strengths that need to be mentioned. The study is retrospective, and the choice of variables was limited. Data collection was dependent on victim's report, and it is not clear how reliable it is to collect data within the context of a forensic examination shortly after a sexual assault because of peritraumatic dissociation. Some women did not recall or were unwilling to relate assault details. Although no more than 17 of responses were missing for any one variable, it is possible that these missing data could have affected study findings. Data are collected from one hospital that in most cases probably would reduce generalizability, but as all sexual assault victim care in the Matara district are centralized to one unit, these are the circumstances that give strength to the study.

\section{Conclusions}

Some of the police areas have a higher percentage of cases reported than the others and the reason for these high percentages should be studied separately. Majority of the victims were children below 16 years of age belonging to lower socio-economic group. Majority had given "consent" for the alleged act and this could be a reason for lack of extragenital injuries together with delayed presentation. This data highlights the magnitude of juvenile sexual abuse especially by the older boy friends and other known people. Sexual assaults committed by an unknown person comprise a low percentage in this study when compared with studies from the United Kingdom and the United States. A different pattern of hymenal injuries were observed for different types of hymens and this type of pattern has not been described in the literature and further studies should be carried out to get further information in this regard.

\section{References}

1. Tharp AT, DeGue S, Valle LA, Brookmeyer KA, Massetti GM. A Systematic Qualitative Review of Risk and Protective Factors for Sexual Violence Perpetration. Trauma, violence and abuse. Published online on 27 December 2012. Available at http://tva.sagepub.com/content/early/201 2/12/27/1524838012470031

2. Black MC, Basile KC, Breiding MJ, Smith SG, Walters ML, Merrick MT, Chen J, \& Stevens MR (2011). The National Intimate Partner and Sexual Violence Survey (NISVS): 2010 Summary Report. Atlanta, GA: Centers for Disease Control and Prevention.

3. Möller A.S, Bäckström T, Söndergaard HP, Helström L. Patterns of Injury and Reported Violence Depending on Relationship to Assailant in Female Swedish Sexual Assault Victims. Journal of Interpersonal Violence 2012;27(16): 3131-3148

4. De Silva H. Second country report on the implementation of the convention on the rights of the child. Department of Probation and Childcare Services, Ministry of Social Services Sri Lanka 1998. 
5. Jones, JS, Wynn, BN, Kroeze B, Dunnuck C, Rossman L. Comparison of sexual assaults by strangers versus known assailants in a community-based population. American Journal of Emergency Medicine 2004; 22, 454-459.

6. Palmer CM, McNulty AM, Déste C, Donovan B. Genital injuries in women reporting sexual assault. Sex Health 2004; 1, 55-59.

7. Slaughter L, Brown CR. Patterns of genital injury in female sexual assault victims. American Journal of Obstetrics \& Gynecology 1997; 176, 609-616.

8. Stermac LE, Du Mont JA, Kalemba V. Comparison of sexual assaults by strangers and known assailants in an urban population of women. Canadian Medical Association Journal 1995; 153, 1089-1094.
9. Sugar NF, Fine DN, Eckert LO. Physical injury after sexual assault: Findings of large case series. American Journal of Obstetrics \& Gynecology 2004; 190, 71-76.

10. Grossin C, Sibille I, Lorin de la Grandmaison, G, Banasr A, Brion F, \& Durigon M. Analysis of 418 cases of sexual assault. Forensic Science International 2003; 131, 125-130.

11. Logan TK, Cole J, Capillo A. Differential characteristics of intimate partner: Acquaintance, and stranger rape survivors examined by a sexual assault nurse examiner. Journal of Interpersonal Violence 2007; 22, 1066-1076.

12. Maguire W, Goodall E, Moore T. Injury in adult female sexual assault complainants and related factors. European Journal of Obstetrics \& Gynecology and Reproductive Biology 2009; 42, 149-153. 